\title{
Analysis on the Applicability of Building Pension Model among Community Courtyard
}

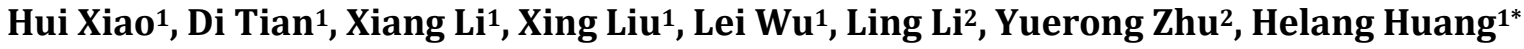 \\ 1Jiangxi Province Key Laboratory of Preventive Medicine, Nanchang University, Nanchang, China \\ 2Qingshan Lake Community Health Service Center, Nanchang, China \\ Email: *hhlang0821@sina.com
}

How to cite this paper: Xiao, H., Tian, D. Li, X., Liu, X., Wu, L., Li, L., Zhu, Y.R. and Huang, H.L. (2018) Analysis on the Applicability of Building Pension Model among Community Courtyard. Open Journal of Social Sciences, 6, 73-79.

https://doi.org/10.4236/jss.2018.66007

Received: May 1, 2018

Accepted: May 20, 2018

Published: May 23, 2018

\begin{abstract}
This study combines the current situation in Nanchang and the available resources in the community to develop the applicability and conditional analysis with the construction of a new model among community courtyard pension for the "Five conceptions and Six features" based on Internet plus. It's aimed at providing guidance. According to the regulations of the National Natural Science Foundation in China, 258 community managers (some residents) and 200 residents representative were selected. The population of the four communities surveyed was 19,506, of whom $\geq 60$ accounted for $12.39 \%$. Among the investigated subjects, $46.51 \%$ were middle school students and $38.37 \%$ were workers. There were significant differences between different education levels and occupations $\left(\chi_{\text {culture }}^{2}=97.662, \mathrm{P}<0.001, \chi_{\text {occupation }}^{2}=70.245, \mathrm{P}<\right.$ $0.001)$. The ideal degree of the building conditions of the courtyard building is Xiao jin tai. There are six items in the analysis of its ten indicators. Such as very convenient for shopping (90.90\%), ideal for health care $(72.72 \%)$ and so on .There are significant differences between the number of children and the monthly income in the two types mode among Community Courtyard ( $\chi^{2}$ children $\left.=16.410, \mathrm{P}<0.05, \chi_{\text {income }}^{2}=14.389, \mathrm{P}<0.05\right)$. The community in Nanchang City basically has the conditions for the construction of the pension model among Community Courtyard, and residents have a high degree of acceptance.
\end{abstract}

\section{Keywords}

Pension Model, Community Health Service, Aging, Nanchang

\section{Introduction}

The pension is not only a social issue with strong policies, but also a technical problem that must be explored in the course of changes in our life [1]. The pension model has become a major hot spot for the elderly lifestyle selection 
among Community Courtyard [2] [3] [4]. This is the background of the home-based pension model. The author's team proposes a new type of pension model. Its biggest feature is combined with the availability of resources in China's urban communities, such as the Internet, health service systems, human resources, community organization forms, and excellent traditional culture, and based on the preliminary practice, the country is Funded by the Natural Science Foundation of China as a project declaration, what the author proposes in this article is the fund project baseline research.

\section{Materials and methods}

\subsection{Survey Objects}

According to relevant requirements of the National Natural Science Foundation of China, the research site is represented by 4 representative communities in Nanchang. Research object inclusion criteria: Community management personnel and residents representatives who are involved in retirement work can support and cooperate with the survey and provide all the information needed for the investigation.

\subsection{Method and Content}

Stratified random sampling was used to conduct a centralized questionnaire and partial discussion. Contents of the questionnaires of community management personnel: including the convenience of community life; contents of questionnaires of individual residents in the community. After data and information were collected, Epidata 3.0 and SPSS 17.0 software were used for data processing.

\section{Results}

\subsection{The Situation of Community Managers and Some Residents}

The author selected 258 managers and part of the relevant representatives to carry out an investigation. The ratio of men and women was $43.80 \%: 56.20 \%$, and the statistical analysis showed that there was no significant difference between the sexes $(2=1.102, \mathrm{P}>0.05)$, and the highest level of high school education was among the subjects, and the occupations were the highest among the workers. There were significant differences between them $(\mathrm{P}<0.01)$, and the results were detailed in Table 1.

\subsection{The Relevant Conditions of Pension Mode among Community Courtyard}

According to the results of the survey, it is found that the courtyard style pension mode of Xiao Jin Tai building has more advantages, and six of the ten conditions are the first. They are "very convenient shopping, ideal health care and health care, sufficient conditions for property maintenance, perfect community communication network, perfect spiritual comfort, and construction of electronic system for health management." secondly, good adaptability for 
Table 1. Basic situation analysis of some community managers and residents in Nanchang.

\begin{tabular}{|c|c|c|c|c|c|c|c|c|c|}
\hline & & $\begin{array}{l}\text { Qing } \\
\text { shan } \\
\text { Lake }\end{array}$ & $\begin{array}{l}\text { Dong } \\
\text { Jia } \\
\text { Yao }\end{array}$ & $\begin{array}{c}\text { Xiaojin } \\
\text { tai }\end{array}$ & $\begin{array}{l}\text { Bao jia } \\
\text { xiang }\end{array}$ & Total & $\begin{array}{c}\text { constitute } \\
\text { ratio } \\
(\%)\end{array}$ & $\chi^{2}$ & $P$ \\
\hline & Total & 47 & 91 & 61 & 59 & 258 & 100.00 & & \\
\hline \multirow{2}{*}{ Gender } & Male & 19 & 40 & 25 & 29 & 113 & 43.80 & 1.102 & 0.777 \\
\hline & Female & 28 & 51 & 36 & 30 & 145 & 56.20 & & \\
\hline \multirow{3}{*}{ Education } & Primary & 13 & 6 & 25 & 14 & 58 & 22.48 & 97.662 & 0.000 \\
\hline & Junior & 28 & 23 & 31 & 38 & 120 & 46.51 & & \\
\hline & College or above & 6 & 62 & 5 & 7 & 80 & 31.01 & & \\
\hline \multirow{4}{*}{ Profession } & Worker & 31 & 11 & 35 & 22 & 99 & 38.37 & 70.245 & 0.000 \\
\hline & Business & 8 & 19 & 10 & 22 & 59 & 22.87 & & \\
\hline & $\begin{array}{l}\text { Administration and } \\
\text { science }\end{array}$ & 2 & 22 & 3 & 5 & 32 & 12.40 & & \\
\hline & other & 6 & 39 & 13 & 10 & 68 & 26.36 & & \\
\hline
\end{tabular}

Bao Jia xiang, compared to Qingshan Lake and Dong Jia yao two communities, in addition to transportation facilities $(89.36 \%, 89.01 \%$ respectively) other conditions to be promoted. A comprehensive comparison of the conditions for the construction of pension mode in the four communities shows that there are significant differences in other conditions except for the response ability of the emergency rescue and the nearby public transport facilities. The results are shown in Table 2 ( $a$ is convenient, $b$ is less convenient, $c$ is inconvenient).

\subsection{Resident Representative's Adaptability to the New Model of Pension Mode among Community Courtyard}

The results of the resident representative survey showed that in 7 aspects of living form, number of children and monthly income, $65 \%$ of them were living with their partners, the monthly income of $57.5 \%$ persons was 2000 - 4000 yuan, and the monthly pension costs of the $66 \%$ were less than 500 yuan; the $58.5 \%$ way to solve the problem was to seek help for spouses and children, and $100 \%$ of the subjects were intelligent. Modern communication tools such as mobile phones, elderly machines and telephone watches. The information indicates that there is a good degree of adaptability to the building hospital endowment. The results are shown in Table 3.

\section{Discussion}

\subsection{Analysis of the Adaptation of Pension Mode with the Current Community}

According to the results, the author believes that the "Five conceptions and Six features" has a universal adaptability to the community. From the objective reality of the community, we can see that it is densely populated with large areas of public activities and places of entertainment, familiar cultural environment 
Table 2. Distribution and comparison of ideal conditions for the construction of old-age care in some communities in Nanchang city.

\begin{tabular}{|c|c|c|c|c|c|c|c|c|c|c|c|c|c|c|}
\hline $\begin{array}{l}\text { Endowment } \\
\text { condition }\end{array}$ & Bao & jia xiang( & 59) & & o jintai( & & Qing & shan lake & (47) & & ngjia yao & (91) & $\chi^{2}$ & $P$ \\
\hline $\begin{array}{l}\mathrm{b}=\text { less } \\
\text { convenient, } \mathrm{c}= \\
\text { inconvenient }\end{array}$ & $a(\%)$ & $\mathrm{b}(\%)$ & $c(\%)$ & $a(\%)$ & $\mathrm{b}(\%)$ & $c(\%)$ & $a(\%)$ & $\mathrm{b}(\%)$ & $c(\%)$ & $a(\%)$ & $\mathrm{b}(\%)$ & $c(\%)$ & & \\
\hline Shopping & $\begin{array}{c}46 \\
(77.78)\end{array}$ & $\begin{array}{c}13 \\
(22.22)\end{array}$ & 0 & $\begin{array}{c}55 \\
(90.90)\end{array}$ & $\begin{array}{c}6 \\
(9.10)\end{array}$ & 0 & $\begin{array}{c}13 \\
(27.66)\end{array}$ & $\begin{array}{c}34 \\
(72.34)\end{array}$ & 0 & $\begin{array}{c}40 \\
(43.96)\end{array}$ & $\begin{array}{c}41 \\
(45.05)\end{array}$ & $\begin{array}{c}10 \\
(11.00)\end{array}$ & 26.066 & 0.000 \\
\hline $\begin{array}{l}\text { Medical and } \\
\text { health care }\end{array}$ & $\begin{array}{c}39 \\
(66.67)\end{array}$ & $\begin{array}{c}20 \\
(33.33)\end{array}$ & 0 & $\begin{array}{c}44 \\
(72.72)\end{array}$ & $\begin{array}{c}17 \\
(27.27)\end{array}$ & 0 & $\begin{array}{c}4 \\
(8.51)\end{array}$ & $\begin{array}{c}42 \\
(89.36)\end{array}$ & $\begin{array}{c}1 \\
(2.12)\end{array}$ & $\begin{array}{c}35 \\
(38.46)\end{array}$ & $\begin{array}{c}43 \\
(47.25)\end{array}$ & $\begin{array}{c}13 \\
(14.29)\end{array}$ & 36.035 & 0.000 \\
\hline $\begin{array}{l}\text { Emergency } \\
\text { response ability }\end{array}$ & $\begin{array}{c}39 \\
(66.67)\end{array}$ & $\begin{array}{c}20 \\
(33.33)\end{array}$ & 0 & $\begin{array}{c}28 \\
(45.45)\end{array}$ & $\begin{array}{c}33 \\
(54.55)\end{array}$ & 0 & $\begin{array}{c}24 \\
(51.06)\end{array}$ & $\begin{array}{c}22 \\
(46.81)\end{array}$ & $\begin{array}{c}1 \\
(2.12)\end{array}$ & $\begin{array}{c}42 \\
(46.15)\end{array}$ & $\begin{array}{c}47 \\
(51.65)\end{array}$ & $\begin{array}{c}2 \\
(2.20)\end{array}$ & 2.459 & 0.888 \\
\hline $\begin{array}{l}\text { Encounter } \\
\text { difficulties }\end{array}$ & $\begin{array}{c}59 \\
(100.00)\end{array}$ & 0 & 0 & $\begin{array}{c}39 \\
(63.63)\end{array}$ & $\begin{array}{c}22 \\
(36.37)\end{array}$ & 0 & $\begin{array}{c}6 \\
(12.77)\end{array}$ & $\begin{array}{c}41 \\
(87.23)\end{array}$ & 0 & $\begin{array}{c}52 \\
(57.14)\end{array}$ & $\begin{array}{c}36 \\
(39.56)\end{array}$ & $\begin{array}{c}3 \\
(3.30)\end{array}$ & 43.616 & 0.000 \\
\hline $\begin{array}{c}\text { Property } \\
\text { maintenance }\end{array}$ & $\begin{array}{c}13 \\
(22.22)\end{array}$ & $\begin{array}{c}26 \\
(44.44)\end{array}$ & $\begin{array}{c}20 \\
(33.33)\end{array}$ & $\begin{array}{c}28 \\
(45.45)\end{array}$ & $\begin{array}{c}33 \\
(54.55)\end{array}$ & 0 & $\begin{array}{c}7 \\
(14.89)\end{array}$ & $\begin{array}{c}38 \\
(80.85)\end{array}$ & $\begin{array}{c}2 \\
(4.26)\end{array}$ & $\begin{array}{c}31 \\
(34.07)\end{array}$ & $\begin{array}{c}55 \\
(60.44)\end{array}$ & $\begin{array}{c}5 \\
(5.49)\end{array}$ & 28.419 & 0.000 \\
\hline $\begin{array}{c}\text { Community- } \\
\text { based } \\
\text { network }\end{array}$ & $\begin{array}{c}33 \\
(55.56)\end{array}$ & $\begin{array}{c}26 \\
(44.44)\end{array}$ & 0 & $\begin{array}{c}55 \\
(90.90)\end{array}$ & $\begin{array}{c}6 \\
(9.10)\end{array}$ & 0 & $\begin{array}{c}8 \\
(17.02)\end{array}$ & $\begin{array}{c}39 \\
(83.98)\end{array}$ & 0 & $\begin{array}{c}59 \\
(64.84)\end{array}$ & $\begin{array}{c}28 \\
(30.77)\end{array}$ & $\begin{array}{c}4 \\
(4.40)\end{array}$ & 42.235 & 0.000 \\
\hline $\begin{array}{l}\text { Entertainment } \\
\text { and sports sites }\end{array}$ & $\begin{array}{c}33 \\
(55.56)\end{array}$ & $\begin{array}{c}26 \\
(44.44)\end{array}$ & 0 & $\begin{array}{c}33 \\
(54.55)\end{array}$ & $\begin{array}{c}28 \\
(45.45)\end{array}$ & 0 & $\begin{array}{c}2 \\
(4.26)\end{array}$ & $\begin{array}{c}36 \\
(76.60)\end{array}$ & $\begin{array}{c}9 \\
(19.15)\end{array}$ & $\begin{array}{c}35 \\
(38.46)\end{array}$ & $\begin{array}{c}41 \\
(45.05)\end{array}$ & $\begin{array}{c}15 \\
(16.48)\end{array}$ & 29.253 & 0.000 \\
\hline $\begin{array}{l}\text { Spiritual } \\
\text { consolation }\end{array}$ & $\begin{array}{c}20 \\
(33.33)\end{array}$ & $\begin{array}{c}33 \\
(55.56)\end{array}$ & $\begin{array}{c}6 \\
(11.1)\end{array}$ & $\begin{array}{c}44 \\
(72.72)\end{array}$ & $\begin{array}{c}11 \\
(18.18)\end{array}$ & $\begin{array}{c}6 \\
(9.10)\end{array}$ & $\begin{array}{c}3 \\
(6.38)\end{array}$ & $\begin{array}{c}31 \\
(65.96)\end{array}$ & $\begin{array}{c}13 \\
(27.66)\end{array}$ & $\begin{array}{c}31 \\
(34.07)\end{array}$ & $\begin{array}{c}34 \\
(37.36)\end{array}$ & $\begin{array}{c}26 \\
(28.57)\end{array}$ & 26.722 & 0.000 \\
\hline $\begin{array}{c}\text { Health } \\
\text { management } \\
\text { electronic } \\
\text { system }\end{array}$ & $\begin{array}{c}20 \\
(33.33)\end{array}$ & $\begin{array}{c}39 \\
(66.67)\end{array}$ & 0 & $\begin{array}{c}22 \\
(36.36)\end{array}$ & $\begin{array}{c}28 \\
(45.45)\end{array}$ & $\begin{array}{c}11 \\
(18.18)\end{array}$ & $\begin{array}{c}8 \\
(17.02)\end{array}$ & $\begin{array}{c}38 \\
(80.85)\end{array}$ & $\begin{array}{c}1 \\
(2.12)\end{array}$ & $\begin{array}{c}27 \\
(29.67)\end{array}$ & $\begin{array}{c}41 \\
(45.05)\end{array}$ & $\begin{array}{c}23 \\
(25.27)\end{array}$ & 22.633 & 0.000 \\
\hline $\begin{array}{l}\text { Public transport } \\
\text { facilities }\end{array}$ & $\begin{array}{c}39 \\
(66.67)\end{array}$ & $\begin{array}{c}20 \\
(33.33)\end{array}$ & 0 & $\begin{array}{c}50 \\
(81.82)\end{array}$ & $\begin{array}{c}11 \\
(18.18)\end{array}$ & 0 & $\begin{array}{c}42 \\
(89.36)\end{array}$ & $\begin{array}{c}5 \\
(10.64)\end{array}$ & 0 & $\begin{array}{c}81 \\
(89.01)\end{array}$ & $\begin{array}{c}10 \\
(10.99)\end{array}$ & 0 & 8.776 & 0.184 \\
\hline
\end{tabular}

(family, neighborhood, friends), can better alleviate the social pressure of the elderly and make the elderly feel safe .It provides an ideal environment for their aged care. Wang Xinghang and others have studied this point [5]; the adaptability of this model is also manifested in the family members' emotional interdependence, the community's existing resources are fully utilized, and the reduction of serious aging brings Professional pension institutions and the pressure of poor economic individuals.

\subsection{Attitudes of Respondents to the Conditions of Community Care}

According to the analysis of the survey results, community managers and some residents are basically in recognition of pension model among community courtyard. There are no significant differences in terms of education level and occupation. The main reasons are as follows: First, these research sites all have a good economic and social basis, especially Xiao jin tai has advantages, such as 
Table 3. Existing objective conditions and statistical analysis of pensions for residents in different communities.

\begin{tabular}{|c|c|c|c|c|c|c|c|c|}
\hline Living conditions & & $\begin{array}{c}\text { Baojia } \\
\text { xiang }\end{array}$ & Xiao jintai & $\begin{array}{l}\text { Qingshan } \\
\text { lake }\end{array}$ & Dongjia yao & Total & $\chi^{2}$ & $P$ \\
\hline \multirow{5}{*}{$\begin{array}{l}\text { Form of resi- } \\
\text { dence }\end{array}$} & With companion & 31 & 32 & 32 & 35 & 130 & 2.543 & 0.864 \\
\hline & \multirow[b]{2}{*}{ With children } & 11 & 14 & 12 & 10 & 47 & & \\
\hline & & 22.00 & 28.00 & 24.00 & 20.00 & 23.00 & & \\
\hline & \multirow{2}{*}{ Live alone } & 8 & 4 & 6 & 5 & 23 & & \\
\hline & & 16.00 & 8.00 & 12.00 & 10.00 & 12.00 & & \\
\hline \multirow{6}{*}{$\begin{array}{l}\text { Number of } \\
\text { children }\end{array}$} & \multirow{2}{*}{0} & 1 & 0 & 0 & 1 & 2 & 16.410 & 0.012 \\
\hline & & 2.00 & & & 2.00 & 0.01 & & \\
\hline & \multirow{2}{*}{$1 \sim 2$} & 26 & 44 & 34 & 44 & 148 & & \\
\hline & & 52.00 & 88.00 & 68.00 & 88.00 & 74.00 & & \\
\hline & \multirow{2}{*}{$2 \sim$} & 13 & 6 & 16 & 8 & 43 & & \\
\hline & & 26.00 & 12.00 & 32.00 & 16.00 & 21.50 & & \\
\hline \multirow{6}{*}{$\begin{array}{l}\text { Monthly income } \\
\text { / yuan }\end{array}$} & \multirow{2}{*}{$<2000$} & 20 & 14 & 13 & 5 & 52 & 14.389 & 0.022 \\
\hline & & 40.00 & 28.00 & 26.00 & 10.00 & 26.00 & & \\
\hline & \multirow{2}{*}{$2000 \sim 4000$} & 24 & 30 & 31 & 30 & 115 & & \\
\hline & & 48.00 & 60.00 & 62.00 & 60.00 & 57.5 & & \\
\hline & \multirow[b]{2}{*}{$>4000$} & 5 & 6 & 6 & 15 & 32 & & \\
\hline & & 10.00 & 12.00 & 12.00 & 30.00 & 16.00 & & \\
\hline \multirow{6}{*}{$\begin{array}{l}\text { Monthly pension } \\
\text { fee / yuan }\end{array}$} & \multirow{2}{*}{$<500$} & 38 & 30 & 35 & 29 & 132 & 8.798 & 0.185 \\
\hline & & 76.00 & 60.00 & 70.00 & 58.00 & 66.00 & & \\
\hline & \multirow{2}{*}{$500 \sim 1500$} & 6 & 8 & 9 & 6 & 29 & & \\
\hline & & 12.00 & 16.00 & 18.00 & 12.00 & 14.50 & & \\
\hline & \multirow{2}{*}{$>1500$} & 6 & 12 & 6 & 15 & 39 & & \\
\hline & & 12.00 & 24.00 & 12.00 & 30.00 & 19.50 & & \\
\hline \multirow{6}{*}{ Health } & \multirow{2}{*}{ fine } & 29 & 40 & 34 & 39 & 142 & 8.623 & 0.144 \\
\hline & & 58.00 & 80.00 & 68.00 & 78.00 & 71.00 & & \\
\hline & \multirow{2}{*}{ Self-care } & 19 & 8 & 15 & 10 & 52 & & \\
\hline & & 38.00 & 16.00 & 30.00 & 20.00 & 26.00 & & \\
\hline & Need to be taken & 2 & 2 & 1 & 1 & 6 & & \\
\hline & care & 4.00 & 4.00 & 2.00 & 2.00 & 3.00 & & \\
\hline \multirow{8}{*}{ Recourse } & \multirow{2}{*}{ spouse } & 23 & 32 & 31 & 31 & 117 & 13.344 & 0.251 \\
\hline & & 46.00 & 64.00 & 62.00 & 62.00 & 58.50 & & \\
\hline & \multirow{2}{*}{ children } & 22 & 13 & 16 & 16 & 67 & & \\
\hline & & 44.00 & 26.00 & 32.00 & 32.00 & 33.50 & & \\
\hline & \multirow{2}{*}{ friend } & 1 & 4 & 2 & 0 & 7 & & \\
\hline & & 2.00 & 8.00 & 4.00 & & 3.50 & & \\
\hline & \multirow{2}{*}{ others } & 4 & 1 & 1 & 3 & 9 & & \\
\hline & & 8.00 & 2.00 & 2.00 & 6.00 & 4.50 & & \\
\hline
\end{tabular}


convenient shopping, ideal medical and health care conditions, and popularization of electronic communications. Second, the investigated community has actively cooperated with the survey and information collection on the health problems of the elderly and related work over the years and has received more knowledge including pension. Thirdly, the Bao jia xiang community in particular embodies a good neighborhood relationship, which is undoubtedly of positive significance for the development of institutional pensions. Fourth, with the development of social economy and the implementation of people's livelihood projects, hardware facilities including pensions are increasingly convenient [6] [7], such as sound community entertainment and sports venues, medical aid conditions, and more convenient transportation. According to Jiang Xiaopu, elderly people are physically and mentally healthy through participation in fitness and various recreational activities [8].

\subsection{The Analysis of the Applicability of Resident Representative's Own Condition to the Pension Model among Community Courtyard}

The author's survey of 200 community resident representatives showed that the pension intentions reflected by the author are basically consistent with those of the above communities, indicating that the venues and objects of "building/institutional" pension selection have certain objectivity and pertinence. The practical application of the model provides a certain degree of protection. The main basis for this is that up to $77 \%$ of the residents' representatives live with their "historic partner" and "living alone". The majority of elderly people have 1-2 children, suggesting that these conditions are suitable for the model of the old-age pension. This is inconsistent with the survey results of You Xueqin and others. He believes that the elderly in the apartment are happier, but the reasons he explained are considered to be closely related to child support, positive self-evaluation, and good attitude [9]. The author believes that these factors can implement the spatial transfer, that is, from the apartment to the community, the essence of which lies in the cultural factors such as the concept of pension and the value orientation. With regard to personal monthly income and pension expenses, $66 \%$ of residents spend less than 500 yuan on pensions. Consumption like this is difficult to adapt to pensions in apartments and professional institutions [10], while community-based pensions are relatively cost-effective Lower, applicable to such a consumer and income group; it is particularly worthwhile to mention that all the investigated objects have modern communication tools specially adapted to the conditions required by the model, which is consistent with the survey of Yu Duchen et al. [11].

\section{Funding}

This work was funded by the National Natural Science Foundation of China, NO.71663037. 


\section{References}

[1] Li, X.Y. and Fan, W. (2014) Advances in Geriatrics 2014. Beijing; People's Medical Publishing House, 1-195.

[2] Tseng, K.C., Wong, A.M., Hsu, C.L., et al. (2013) The i Fit: An Integrated Physical Fitness Testing System to Evaluate the Degree of Physical Fitness of the Elderly. IEEE Trans Biomed Eng, 60, 184-188. https://doi.org/10.1109/TBME.2012.2211357

[3] Wu, Y.X. (2013) Development Report on China's Old Age Careers. Social Sciences Academic Press, Beijing, 5-10.

[4] Huang, L., Xu, Y., Yi, Y., et al. (2015) Epidemic Characteristics of Chinese Geriatric Diseases and Their Prevention and Control Strategies. Chinese Journal of Gerontology, 01, 248-251.

[5] Wang, X.H. and Zhou, F. (2017) Analysis of Outdoor Appropriate Space Design and Communication Impact of Community Elderly. Chemical Industry Management, No. 35, 148.

[6] Guo, M., Yue, B., Sun, Q.H., et al. (2015) The Economic Burden of Population Aging and Disease in China. Medical Science and Philosophy, No. 7, 32-34.

[7] Fisher, S.R., Kuo, Y.F., Graham, J.E., et al. (2010) Early Ambulation and Length of Stay in Older Adults Hospitalized for Acute Illness. Arch Intern Med, 170, 1942-1943. https://doi.org/10.1001/archinternmed.2010.422

[8] Martin, L.G., Schoeni, R.F., Andreski, P.M., et al. (2012) Trends and Inequalities in Late-Life Health and Functioning in England. J Epidemiol Community Health, 66, 874-880. https://doi.org/10.1136/jech-2011-200251

[9] You, X.Q., Yin, S.Y., Guo, C. and Teng, Z.J. (2018) The Mediating Role of Subjective Well-Being and Psychological Health in the Elderly in Apartments. Chinese Journal of Gerontology, No. 06, 1484-1486.

[10] Huang, H.L., Wu, L., Zhang, J.Y., Deng, P.F., Long, Y., Lin, F. and Zhou, J.M. (2016) Building and Thinking about the Information Ageing Mode of the "Five All-Energy" Community Building in an Aging and Aging Society. Chinese Health Service Management, 33, 498-500.

[11] Dang, D.C. and Peng, Q.C. (2017) Analysis of the Construction Foundation of the "Internet + Community Home-based Pension Care" Service Model in Chinese Cities. Social Security Research, No. 03, 18-26. 